Zabalbeascoa, P. and Arias-Badia, B. (2021). The HispaTAV translation techniques for subtitling: A new pedagogical resource for audiovisual translation students. Current Trends in Translation Teaching and Learning E, 8, 359 - 393. https://doi.org/10.51287 /cttle20218

\title{
THE HISPATAV TRANSLATION TECHNIQUES FOR SUBTITLING: A NEW PEDAGOGICAL RESOURCE FOR AUDIOVISUAL TRANSLATION STUDENTS
}

Patrick Zabalbeascoa and Blanca Arias-Badia

Universitat Pompeu Fabra

\section{Abstract}

Being able to propose a taxonomy of translation techniques has been a long-standing aspiration of translation theorists. By building on previous proposals, this paper presents the HispaTAV typology of translation techniques (ToT), a new list specifically designed for subtitling trainees. The aim of the proposal is to increase students' awareness of the variety of possible solutions to translate segments of the source text, and to promote creativity, a key factor in the development of translator competence. The proposal has been presented to current translation students, who have provided feedback in terms of its usability for learning purposes.

Keywords: translation techniques, subtitling, HispaTAV, audiovisual translation, translator competence 
Zabalbeascoa, P. and Arias-Badia, B. (2021). The HispaTAV translation techniques for subtitling: A new pedagogical resource for audiovisual translation students. Current Trends in Translation Teaching and Learning E, 8, 359 - 393. https://doi.org/10.51287 /cttle20218

\section{INTRODUCTION}

Being able to propose a list, or taxonomy, of translation techniques has been a long-standing aspiration of translation theorists, especially when theorists see their job as enlightening the education of trainees, in some sort of master / apprentice relationship, and sometimes, even beyond that. There is not room enough in this article to do justice to the full amount of studies and proposals searching for a definitive list of translation techniques. So, we will necessarily be selective in authors mentioned and points to be made for the specific purpose of our account. The main objective herein is to offer a learning tool for trainee translators, with a particular focus on audiovisual translation, and even more specifically, in this particular instance, for future subtitlers. The basis of the pedagogical resource is to provide a list of types of translation techniques (ToTs), with samples, in order to enhance awareness of the broad range of possible solution types and encourage students to be bolder in their own proposed translations for particular translation problems, rather than cling to solutions that are perceived to be safe, mechanical, objective. We feel that samples drawn from real-life subtitles (and other varieties of audiovisual translation) will lend greater credibility and stability to a proposal based on empirical data. At the same time, the data can inform a model of labelling translation solutions according to types or relevant characteristics.

We intend to address an issue of certain published proposals (e.g. Vinay \& Darbelnet, 1958; Newmark, 1988; Molina \& Hurtado, 2001), going for too many situations and varieties of 
Zabalbeascoa, P. and Arias-Badia, B. (2021). The HispaTAV translation techniques for subtitling: A new pedagogical resource for audiovisual translation students. Current Trends in Translation Teaching and Learning E, 8, 359 - 393. https://doi.org/10.51287 /cttle20218

translation in a somewhat unstated claim that the list of techniques is universal, and, further, a certain hint that the list is (aimed to be) a taxonomy, with no overlapping categories, which would obviously be desirable terminologically. Here, we do not aim to be taxonomical, nor do we aim, in the first instance, to claim validity beyond scope of subtitling, though we must admit there is an aspiration to broaden the scope gradually, step by step; first, on to dubbing, then other varieties of AVT. If the list is not taxonomical, students need to be shown, before searching for samples of each label, that a single instance of translation (found in subtitles) may appropriately represent more than one label, or type, without that being a problem. In any case, every effort has been made to avoid this as much as possible.

One of the points we felt needed to be addressed was the notion that translation techniques pivot on the comparison of a text (T1) to its translation (T2), largely based on contrastive linguistics, and the name of the technique is somehow a label that describes the kind of operation that led from wording in a segment of T1 to its rendering in $\mathrm{T} 2$, related to correspondences between a pair of languages. The HispaTAV proposal, on the other hand, involves a list of types of translation techniques (ToTs) based on the comparison of various T2 solutions found in empirical studies with regard to what the T2 segments would have looked like had they each been translated literally, or according to an ideal transference (with all the words, nuances, ideas and meanings included in the T1 segments, assuming literal equivalents could be found for all of them), or according to systemic correspondences (Krzeszowski, 2016). So, ToTs like omission and reduction do not refer to cutting or reducing 
Zabalbeascoa, P. and Arias-Badia, B. (2021). The HispaTAV translation techniques for subtitling: A new pedagogical resource for audiovisual translation students. Current Trends in Translation Teaching and Learning E, 8, 359 - 393. https://doi.org/10.51287 /cttle20218

anything directly from the $\mathrm{T} 1$, but an omission or reduction compared to what a literal translation would have looked like in T2. From this angle, "literal translation" is to be considered either a default technique or a non-technique. In most of the literature, literal translation figures prominently as a technique, but not here; we see it more as a predefined equivalent, a standard, systemic solution, to be found in dictionaries, phrase books, something fairly easily attainable by machine translation, hardly requiring much human intervention and display of "technique" understood as the result of training or specialized awareness beyond the reach of lay people, other than cases where literal translation may seem counterintuitive or requires expert proficiency in vocabulary, etymology, or style. Our pedagogical aim is to encourage students to dare go beyond the dictionary, so to speak, and explore text-sensitive solutions that are effective and justified by specific communicative factors.

The goal, therefore, is twofold, aiming to increase student awareness and promote creativity, as a pedagogical target for improving translator competence; the other aim is to provide something tangible, i.e., a collection of subtitles that reflect an array, if not the full range, of T2 options for rendering T1 segments of an audiovisual text through subtitling.

The particular case of subtitling demands students' attention to legibility and readability constraints, reading speed and comfort, the need to complement the picture and the audio (Díaz-Cintas \& Remael, 2021, pp. 64-90), and paralinguistic features involved in formatting writing for the screen. These features include colour contrast between letters and background, type of letters, size, positioning on the screen, punctuation, among 
Zabalbeascoa, P. and Arias-Badia, B. (2021). The HispaTAV translation techniques for subtitling: A new pedagogical resource for audiovisual translation students. Current Trends in Translation Teaching and Learning E, 8, 359 - 393. https://doi.org/10.51287 /cttle20218

others (Díaz-Cintas \& Remael, 2021, pp. 118-144). All of these factors can be exploited and must be taken into account when producing subtitles. This is also aimed at stressing the fact that subtitles are not, in the first instance, to be considered as a piece of writing that can be read independently from its original audiovisual context, but rather that the audiovisual is the text, and the subtitling a part of that text, just like the written component of memes. This is not to say that subtitling criteria may include a requirement of separability (Zabalbeascoa, 2008), enabling some subtitles to be read independently from the picture if the aim is to provide them with a certain "quotable" (separable) quality.

\section{TYPES OF TRANSLATION TECHNIQUES: AN OVERVIEW}

There have been many attempts to provide a list of translation techniques, and many different names for almost the same thing (shifts, procedures, strategies), which is naturally confusing for trainees exposed to this kind of literature. Here, we offer a short selection just to show the variety of periods, types of authors, and the degree of repetition and overlap, and potential for terminological confusion, and the difficulty involved in adequately attributing authorship for each technique, many of which, to our mind, should still be explicitly attributed to Vinay and Darbelnet (1958).

Díaz-Cintas and Remael (2021) propose the following "strategies" for subtitling cultural references: loan, calque, 
Zabalbeascoa, P. and Arias-Badia, B. (2021). The HispaTAV translation techniques for subtitling: A new pedagogical resource for audiovisual translation students. Current Trends in Translation Teaching and Learning E, 8, 359 - 393. https://doi.org/10.51287 /cttle20218

literal translation, transposition, compensation, lexical recreation, explicitation, substitution, omission. Molina and Hurtado (2001), in turn, propose the following: loan, calque, literal translation, compensation, transposition, modulation, adaptation, linguistic extension vs linguistic compression, extension vs elision, discursive creation, description, coined equivalent, generalization vs particularization, substitution, variation. Likewise, Vinay and Darbelnet (1958) list these technical procedures: loan, calque, word for word or literal translation, grammatical transposition, compensation, modulation, equivalence, adaptation.

As recently noted by Díaz-Cintas and Remael (2021), "no existing classification can cover all the translation strategies to which translators or subtitlers resort ... overlap is inevitable and strategies are often combined" (p. 207). In short, translation techniques are fraught with issues from a theoretical standpoint, especially any attempt to produce a taxonomy, or a definitive list (Zabalbeascoa, 2000). However, they still hold great appeal as a first approach to translation and, unsurprisingly, in training. Since this is the case, we think it might be pedagogically sound to present the issue to students, with two careful considerations. One is to present typologies of techniques, critically, showing their strengths and weaknesses, as well as an awareness of the variety of proposals. The other is to make sure they promote translators' creativity, adaptability, flexibility, their ability to find the best possible solution for each challenge, and to appreciate such efforts in other translators' work. 
Zabalbeascoa, P. and Arias-Badia, B. (2021). The HispaTAV translation techniques for subtitling: A new pedagogical resource for audiovisual translation students. Current Trends in Translation Teaching and Learning E, 8, 359 - 393. https://doi.org/10.51287 /cttle20218

Descriptive translation studies avoid the use of the term "techniques" and prefer to refer to solutions or renderings, or even coupled pairs of replacing + replaced segments (Toury, 1995), meaning phenomena that can be found empirically (by comparing segments of T1 and T2), or what could hypothetically be resorted to, in a speculative approach, often used as a goal for descriptive studies to search for if no such samples have yet been found. Two interesting proposals come from this approach: first, Toury's (1995) proposal for showing a range of possible solutions for translating metaphors, later picked up and slightly adapted by Delabastita (1996) to produce the most cited classification of ways to translate wordplay (Table 1).

Table 1. Delabastita's (1996) proposal for translating puns

\begin{tabular}{|l|l|}
\hline operation from T1 segment & T2 result \\
\hline translation of T1 pun as pun in T2 & pun \\
\hline translation of T1 segment, without pun effect in T2 & not a pun \\
\hline $\begin{array}{l}\text { related rhetorical device in T2 aiming for similar } \\
\text { effect of T1 pun }\end{array}$ & not a pun \\
\hline omission in T2 of T1 pun segment & not anything \\
\hline
\end{tabular}


Zabalbeascoa, P. and Arias-Badia, B. (2021). The HispaTAV translation techniques for subtitling: A new pedagogical resource for audiovisual translation students. Current Trends in Translation Teaching and Learning E, 8, 359 - 393. https://doi.org/10.51287 /cttle20218

\begin{tabular}{|l|l|}
\hline transcription, transliteration in $\mathrm{T} 2$ of $\mathrm{T} 1$ pun segment & $\mathrm{L} 3$ pun \\
\hline $\begin{array}{l}\text { inserting punning effect in } \mathrm{T} 2 \text { from } \mathrm{T} 1 \text { non-pun } \\
\text { segment (may be compensation) }\end{array}$ & pun \\
\hline $\begin{array}{l}\text { addition of new text material (may be compensation) } \\
\text { in } \mathrm{T} 2\end{array}$ & pun \\
\hline $\begin{array}{l}\text { editorial techniques in } \mathrm{T} 2 \text { to reflect or explain } \mathrm{T} 1 \\
\text { features }\end{array}$ & not a pun \\
\hline
\end{tabular}

From Toury and Delabastita's proposals, Zabalbeascoa (2004, 2018) later develops a model of binary branching to be applied to all translation problems (not only metaphor and wordplay), including non-segmental textual features of T1. The advantage of these proposals is that their starting point is a particular translation problem posed by a $\mathrm{T} 1$ feature (metaphor, humour, irony, etc.) and operations that lead to $\mathrm{T} 2$ solutions that are expressed in terms of how the feature is dealt with, rather than how literal or far-from-literal the translation is, which may not always be informative as to how the $\mathrm{T} 1$ feature was retained in $\mathrm{T} 2$.

Delabastita (1993) has another important contribution within a descriptive methodology, based on five rhetorical operations (substitution, repetition, omission, addition, and permutation) and reveals how these operations affect three different codes (linguistic, cultural and textual), producing fifteen different 
Zabalbeascoa, P. and Arias-Badia, B. (2021). The HispaTAV translation techniques for subtitling: A new pedagogical resource for audiovisual translation students. Current Trends in Translation Teaching and Learning E, 8, 359 - 393. https://doi.org/10.51287 /cttle20218

types of solutions, and applies this non-prescriptive approach to a complete study of Shakespeare's wordplay in translation.

If each proposal is made to raise awareness of the range of possibilities, then probably it is also necessary, from a pedagogical point of view, to offer students an introduction to the variety of proposals and their implications, adapted to their needs and levels. This would be useful to dispel the idea that any single one of these proposals is prior to or above actual translation practice, but rather, that they are conceptual tools, and as such they can be combined and, over time, improved, especially with benefit of collections of relevant samples of reallife translations. Critical, analytic reviews of different proposals, such as Marco's (2004), are essential for these proposals to evolve and they help to create the necessary dialogue among them. Part of the pedagogical dimension of the HispaTAV proposal of ToTs is to allow other proposals to be mentioned and used as a reference when deemed necessary.

\section{THE HISPATAV ToT PROPOSAL}

The first edition of the HispaTAV ToT proposal can be found in Zabalbeascoa (2021). As mentioned in the Introduction, its aim is to serve as a resource for audiovisual translation students, by showing the variety of options available to address the translation of audiovisual products. This section builds on the quoted edition of the proposal and accompanies the description of each type of translation technique by examples taken from real translations published on video-on-demand platforms. 
Zabalbeascoa, P. and Arias-Badia, B. (2021). The HispaTAV translation techniques for subtitling: A new pedagogical resource for audiovisual translation students. Current Trends in Translation Teaching and Learning E, 8, 359 - 393. https://doi.org/10.51287 /cttle20218

It must be noted that in the HispaTAV ToT proposal for subtitler training "translation techniques" is used to mean T2 operations that involve changes with respect to a literal or direct translation, a transliteration or a calque or borrowing. In other words, some solutions can be found in translation for which no technique is needed (e.g. Hello! >> ¡Hola! // I'm here >> estoy aquí // George $\gg$ George // cricket $\gg$ cricket, etc.). However, when transliteration, calque or borrowing may also be seen as the result of a meditated decision, confronted with other alternatives, then they are techniques, from that perspective, and, specifically would be included in ToT1e (see ToT list below).

We also find it useful to distinguish three different planes of techniques: (i) translation techniques (rendering T1 segments or features in T2); (ii) T2 writing techniques (geared towards better, clearer writing, more adjusted to the medium...); (iii) captioning techniques, to conform to subtitling norms and restrictions (reading speeds, lines, screen placement and formatting, readability, etc.). The three planes of techniques must complement each other but not be muddled. In all three cases, the term technique refers to professional skills of the trade of translating, writing and producing subtitles, respectively. This is why literal translation, and systemic correspondences between languages are not the main focus of the proposal, which is more context-sensitive, and dependent on the contingencies of specific acts of (audiovisual) textual communication. 
Zabalbeascoa, P. and Arias-Badia, B. (2021). The HispaTAV translation techniques for subtitling: A new pedagogical resource for audiovisual translation students. Current Trends in Translation Teaching and Learning E, 8, 359 - 393. https://doi.org/10.51287 /cttle20218

What follows is the list of HispaTAV types of techniques (ToTs) for subtitling. There are thirteen types of techniques and eight subtypes on the list, with examples taken from real samples ${ }^{1}$.

\section{ToT1. Rewording}

Rewording entails using different words to express a given idea -typically, rewording takes place when we want to convey an idea in a clear, or appropriate manner. Any interlingual T1 > T2 transfer involves rewording in the different languages used in each text. So, this is the place to remind the reader that the name of this technique is proposed by comparing the $\mathrm{T} 2$ to a hypothetical literal translation of the T1 (i.e., no technique, in the HispaTAV proposal). Likewise, it is worth noting that rewording is also frequent in intralingual subtitling, due to the time-and-space constraints of this translation modality. As explained below, rewording may occur in different ways.

\section{ToTla. Rewording affecting morphosyntactic features}

ToT1a applies whenever parts-of-speech categories, voice, tenses, or word formation (affixes) are modified in the T2. Consider example (1), where the subtitler opts for a verbal periphrasis (se puede operar) to translate the adjective phrase of the T1/No technique, headed by the adjective treatableltratable, which produces a shorter sentence than the one found in the T1/No technique.

\footnotetext{
${ }^{1}$ Each subtitle includes the following information: source text (T1), target text (T2), back translation (BT), hypothetical translation in which no technique is applied (No technique), and source code. The complete list of sources can be consulted in the References section.
} 
Zabalbeascoa, P. and Arias-Badia, B. (2021). The HispaTAV translation techniques for subtitling: A new pedagogical resource for audiovisual translation students. Current Trends in Translation Teaching and Learning E, 8, 359 - 393. https://doi.org/10.51287 /cttle20218

(1) T1: The good news is that it's treatable with surgery and immunotherapy and radiation.

T2: Por suerte se puede operar $\mid$ y tratar con inmunoterapia y radiación.

BT: Luckily, it can be operated and treated with immunotherapy and radiation.

No technique: La buena noticia es que es tratable con cirugía e inmunoterapia y radiación.

[Source: 01]

ToT1b. Rewording affecting lexicosemantic features

ToT1b applies whenever subtitlers reword utterances of the T1 by resorting to different collocations, phrases, or idioms, in the T2. Also, when they opt for changing the meaning of the lexical units making up the $\mathrm{T} 1$ utterance in $\mathrm{T} 2$ to a lesser or to a greater extent, by using synonyms, paronyms, hypernyms to translate a given word of the T1. An example of ToT1b can be found in (2), where the meaning of spoil, which, as 'pamper', is equivalent to Spanish mimar (No technique)- is specified in the T2 engordar (get fatter / gain weight).

(2) T1: Yeah, I know. I'm spoiling myself, but I'm depressed. T2: Ya, voy a engordar, | pero estoy deprimido. BT: I know, I will get fatter, but I'm depressed. No technique: Sí, lo sé. Me estoy mimando, pero estoy deprimido.

[Source: 02] 
Zabalbeascoa, P. and Arias-Badia, B. (2021). The HispaTAV translation techniques for subtitling: A new pedagogical resource for audiovisual translation students. Current Trends in Translation Teaching and Learning E, 8, 359 - 393. https://doi.org/10.51287 /cttle20218

\section{ToT1c. Rewording affecting pragmatic features}

ToT1c applies whenever rewording entails changes in the way in which the information is organised or managed in the utterance, as well as whenever rewording suggests a different attitude from the speaker, i.e., if the translation shows a different tenor of discourse, typically affecting register. Therefore, ToT1c is usually connected to the use or absence of discourse and conversational markers in the translation. Consider (3), in which we find two translation solutions affecting pragmatic features of the utterance: (i) the T1 word shrink, considered offensive in some contexts (Macmillan, n.d.), is rendered by the standard noun psicóloga (psychologist), whereas in Spanish there is a word that could have preserved the register of the T1 (loquera, see No technique); (ii) the T1/No technique shows the pragmatic marker That's why/Por eso, which connects the utterance to the previous one, thus producing a more cohesive dialogue than the one found in the T2, which sounds more like a final, independent statement. The application of ToT1c in (3) contributes to the T2 showing a more formal register than that of the T1. Importantly for subtitling, the technique produces a shorter utterance in the T2 (ToT5).

(3) T1: That's why I say you should never date a shrink.

T2: Nunca se debe salir con una psicóloga.

BT: One must never date a shrink.

No technique: Por eso digo que nunca deberías salir con una loquera.

[Source: 03] 
Zabalbeascoa, P. and Arias-Badia, B. (2021). The HispaTAV translation techniques for subtitling: A new pedagogical resource for audiovisual translation students. Current Trends in Translation Teaching and Learning E, 8, 359 - 393. https://doi.org/10.51287 /cttle20218

ToT1d. Rewording affecting stylistic features

ToT1d applies whenever functional and stylistic elements of the $\mathrm{T} 1$ cannot be rendered in the $\mathrm{T} 2$ straightforwardly. Typical contexts of application of this ToT include utterances with humoristic intent, poetic or singable segments. Two examples of ToT1d can be found in (4) and (5). In (4), the speaker uses two verbs derived from the name of a pop band, Wang Chung, who wrote 'Everybody have fun tonight' in the 80s. Maybe because Wang Chung is not well-known in Spain, the translator opts for an idiom in Spanish (ser la madre de, 'to be the mother of') combined with the colloquial unit desmadres ('crazy parties'), which bears formal similarity with madre. Interestingly, in this case the application of ToT1d produces a longer T2 utterance.

(4) T1: Everybody wanged, everybody chunged.

T2: y ha sido la madre de todos los desmadres.

BT: and it has been the mother of all crazy parties.

No technique: Todo el mundo wangueó, todo el mundo chungueó.

[Source: 04]

In (5), the translator opts for a creative derivation of the noun swing in Spanish: swinguear. In this case, the T1 wordplay is based on the fact that the speaker invites another character to attend some swing auditions by means of the phrasal verb swing by (literally, pasarse, see No technique).

(5) T1: I think you should swing by.

T2: Deberías swinguear.

BT: You should swing. 
Zabalbeascoa, P. and Arias-Badia, B. (2021). The HispaTAV translation techniques for subtitling: A new pedagogical resource for audiovisual translation students. Current Trends in Translation Teaching and Learning E, 8, 359 - 393. https://doi.org/10.51287 /cttle20218

No technique: Creo que deberías pasarte por aquí. [Source: 03]

ToT1e. Rewording involving language variation (L3)

ToT1e applies whenever a third language (L3) in the T1 is not simply transcribed, untranslated, in the T2, or omitted. It must be noted that L3 does not only involve the use of other languages, but also dialects, non-native speech, invented languages, unconventional speech, gibberish, etc. An example of ToT1e can be found in (6), where quotation marks are added in the subtitle to signal the French $\mathrm{T} 1$ utterance.

$$
\text { T1: Je ne regrette nothing, baby. }
$$

T2: "Je ne regrette" nada, guapa.

BT: "Je ne regrette" nothing, baby.

No technique: Yo no me arrepiento de nada, guapa. / Je ne regrette nada, guapa.

[Source: 01]

\section{ToT2. Rewording cultural elements or intertextuality}

ToT2 applies whenever rewording is connected to the presence of cultural elements or intertextuality features in T1. This may include proper nouns, references, allusions, quotations, key words related to a specific ideology (sexism, pacifism, fanaticism, racism, theism), among others. Examples (7) and (8) illustrate ToT2: in (7), the proper name of a chocolate bar present in the T1/No technique (Curly Wurly) is translated by the generic term chocolatina ('chocolate bar').

(7) T1: Give me that Curly Wurly. 
Zabalbeascoa, P. and Arias-Badia, B. (2021). The HispaTAV translation techniques for subtitling: A new pedagogical resource for audiovisual translation students. Current Trends in Translation Teaching and Learning E, 8, 359 - 393. https://doi.org/10.51287 /cttle20218

T2: Dame esa chocolatina.

BT: Give me that chocolate bar.

No technique: Dame esa Curly Wurly.

[Source: 03]

In (8), a fixed expression belonging to the field of liturgy is not translated literally (No technique), but by the expression used in the same context in Spanish. It is worth noting that, in this case, a change of person is at stake as well, so we find a combination of ToT2 and ToT1c.

(8) T1: speak now or forever hold your peace.

T2: que hable ahora o calle para siempre.

BT: [he/she should] speak now or stay silent forever.

No technique: habla ahora o quédate en paz para siempre.

[Source: 06]

\section{ToT3. Paralinguistic marks}

ToT3 entails the use of orthotypographical marks to signal specific elements of the T2, mainly for style and expressive intent. Examples of ToT3 are present in examples (5) and (6) above: in (5) the invented word swinguear is rendered in italics (expressive neologism). In (6), quotation marks signal the presence of an L3. A further example of ToT3 is presented in (9), in which English-speaking fictional characters visiting Greece are given information about a ferry departure in Greek by a local. The subtitler opts for rendering the Greek word in the Latin alphabet, between quotation marks.

(9) T1: $\Delta \varepsilon v \tau \varepsilon ́ p \alpha$ 
Zabalbeascoa, P. and Arias-Badia, B. (2021). The HispaTAV translation techniques for subtitling: A new pedagogical resource for audiovisual translation students. Current Trends in Translation Teaching and Learning E, 8, 359 - 393. https://doi.org/10.51287 /cttle20218

T2: "Deftera"

BT: "Deftera"

No technique: Lunes

[Source: 05]

\section{ToT4. Addition}

Additional elements in T2 appear (by means of paraphrasing, periphrasis, or explicitation, among others) when they cannot be accounted for by mapping T1 segments onto T2. Typically, ToT4 results in a longer version of the utterance than default literal translation. Examples (10) and (11) illustrate ToT4: in (10), the translation specifies, i.e., makes explicit, the fact that by grilled cheese the speaker is referring to a type of sandwich. The time-and-space constraints of subtitling sometimes pave the way for addition to be combined with reduction (ToT5), like in this example, where the semantic content conveyed by the word grilled is not present in T2. (See also the added question tag in (19).)

(10) T1: Grilled cheese.

T2: Sándwich de queso.

BT: Cheese sandwich.

No technique: Queso a la parrilla.

[Source: 07]

In (11), a female character is asking a police officer to leave her home after her son's murder. While the English/No technique version could be interpreted as a rather rude utterance, the translation shows a formal register by opting for the formal $2^{\text {nd }}$ person usted treatment (ToT1c) and producing a longer sentence 
Zabalbeascoa, P. and Arias-Badia, B. (2021). The HispaTAV translation techniques for subtitling: A new pedagogical resource for audiovisual translation students. Current Trends in Translation Teaching and Learning E, 8, 359 - 393. https://doi.org/10.51287 /cttle20218

which specifies the place that the officers are asked to leave (the speaker's home). The punctuation mark selected (.) also conveys a calmer, more formal register than the shouting (expressed as an exclamation in the transcript) of $\mathrm{T} 1$.

\section{(11) T1: Get out!}

T2: Salga de mi casa.

BT: Get out of my house/home.

No technique: ¡Salga! / ¡Fuera [de aquí]!

[Source: 08]

\section{ToT5. Reduction}

We refer to reduction whenever the rewording of the T2 involves total or partial reduction of a hypothetical literal translation of the $\mathrm{T} 1$ contents. This may be the result of devices like synthesis, gist, omission, ellipsis, or increased implicitness, among others. Typically, ToT5 results in a shorter version of the utterance than default literal translation. Consider (12), where the idea of the T1/No technique is abbreviated by only translating the conclusion presented in the utterance. The explicit references to the speaker and the interlocutor are also omitted in the translation, thus producing a more indirect statement (ToT1c).

(12) T1: But I thought you'd want to know the real issue isn't the overtime, it's being understaffed.

T2: Pero el problema real | es la falta de personal.

BT: But the real problem is the lack of staff.

No technique: Pero pensé que querrías saber que el problema real no son las horas extras, es la falta de personal. 
Zabalbeascoa, P. and Arias-Badia, B. (2021). The HispaTAV translation techniques for subtitling: A new pedagogical resource for audiovisual translation students. Current Trends in Translation Teaching and Learning E, 8, 359 - 393. https://doi.org/10.51287 /cttle20218

[Source: 01]

Examples (13) and (14) show a common resource for reduction in subtitling: the use of deixis, related to verbal, contextual information (13), and to non-verbal elements shown in the picture (14).

(13) T1: What would you write to a total stranger? 'Please come to my wedding, you might be my father'?

T2: ¿Crees que podía decírselo? No.

BT: Do you think I could tell them? No.

No technique: ¿Qué le dirías a un absoluto desconocido? "Por favor, ven a mi boda. Podrías ser mi padre".

[Source: 05]

(14) T1: He's selling candy to pay for his basketball uniforms.

T2: Vende esto para pagar | los uniformes de baloncesto.

BT: He sells this to pay for his basketball uniforms.

No technique: Está vendiendo caramelos para pagar sus uniformes de baloncesto.

[Source: 02]

\section{ToT6. Sentence splitting}

ToT6 involves rewording resulting in more sentences in T2 than those in T1. An example of ToT6 can be found in (15), where the non-defining relative clause present in T1/No technique (one of whom has sleeve tats on both arms) is translated by an independent phrase in the subtitle. The example also shows content reduction in the translation, which does not specify the body part in which the tattoo is to be found (ToT5). 
Zabalbeascoa, P. and Arias-Badia, B. (2021). The HispaTAV translation techniques for subtitling: A new pedagogical resource for audiovisual translation students. Current Trends in Translation Teaching and Learning E, 8, 359 - 393. https://doi.org/10.51287 /cttle20218

(15) T1: We're looking for three white males, one of whom has sleeve tats on both arms.

T2: Buscamos a tres hombres blancos. | Uno tatuado.

BT: We're looking for three white men. One [is] tattooed.

No technique: Buscamos a tres hombres blancos, uno de los cuales lleva tatuajes de manga en ambos brazos.

[Source: 02]

\section{ToT7. Sentence blending}

ToT7 applies whenever rewording results in fewer sentences in $\mathrm{T} 2$ than those found in the $\mathrm{T} 1$, as in (16).

(16) T1: Take more. It's only money.

T2: Tranquilo, será por pasta...

BT: Don't worry, money is no problem...

No technique: Coge más. Solo es dinero.

[Source: 06]

\section{ToT8. Combination of different semiotic signs}

ToT8 applies whenever the translation combines verbal elements with non-verbal ones conveyed via the aural or visual channel. Thus, ToT8 may include the following subtechniques:

ToT8a. From non-verbal in the T1 to verbal in the subtitle ToT8a includes those cases in which non-verbal (visual or audio) elements are translated by means of verbal signs. An example of ToT8a is presented in (17), where the gesture of a 
Zabalbeascoa, P. and Arias-Badia, B. (2021). The HispaTAV translation techniques for subtitling: A new pedagogical resource for audiovisual translation students. Current Trends in Translation Teaching and Learning E, 8, 359 - 393. https://doi.org/10.51287 /cttle20218

character flushing, as well as the sound of the toilet flushing is translated by the verb funcionar ('work/flush').

(17) T1: if it doesn't flush right away, just go and come back in a while, and it should...

T2: Si la cisterna no funciona, | volvéis un rato después... // ...y debería funcionar.

BT: If the toilet does not work, come back in a while... and it should work.

No technique: Si no descarga al momento, os vais y volvéis dentro de un rato, y debería...

[Source: 05]

ToT8b. From non-verbal in the T1 to non-verbal in the subtitle ToT8b entails the inclusion of non-verbal signs in the subtitle to translate non-verbal information conveyed in the T1. To date, ToT8b is not easily found in major streaming platforms. An example of ToT8b are the emojis used in creative subtitling designed for the deaf and the hard-of-hearing (SDH) (e.g. the face and cap used in Figure 1) to identify different characters speaking.

Figure 1. Use of emoji as character identification labels in SDH. Source: IRT Mediathek (2020). 
Zabalbeascoa, P. and Arias-Badia, B. (2021). The HispaTAV translation techniques for subtitling: A new pedagogical resource for audiovisual translation students. Current Trends in Translation Teaching and Learning E, 8, 359 - 393. https://doi.org/10.51287 /cttle20218

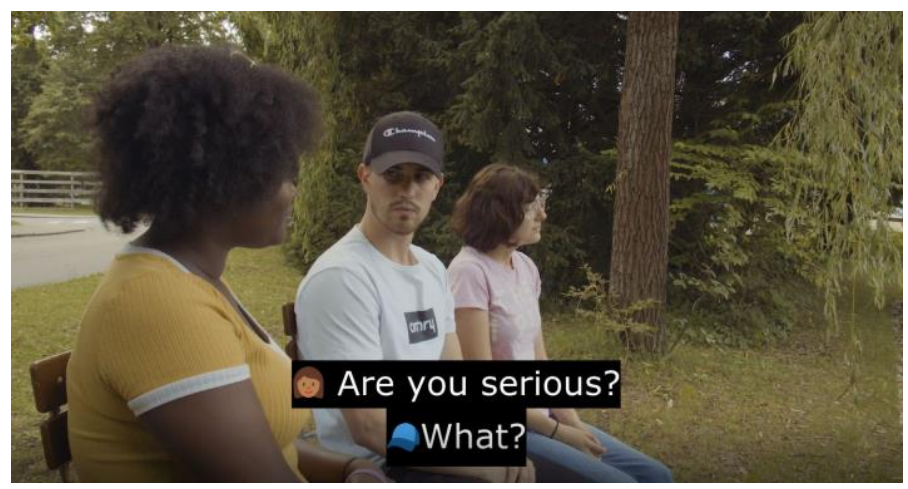

ToT8c. From verbal in the T1 to non-verbal in the subtitle ToT8c entails the inclusion of non-verbal signs in the subtitle to translate verbal information conveyed in the T1. An example of this is the music symbol [ $\delta \delta \delta]$ used sometimes in SDH to account for music with lyrics.

\section{ToT9. Compensation or relocation}

ToT9 involves the translation of any linguistic feature in a different part of the audiovisual product; for example, by rendering a swear word or a pun in the next subtitle, or even further away.

\section{ToT10. Use of translator's (extradiegetic) note}

ToT10 applies whenever we find an explanation added by the subtitler. For example, in Figure 2, we find an extradiegetic note stating the L3 spoken in the scene. 
Zabalbeascoa, P. and Arias-Badia, B. (2021). The HispaTAV translation techniques for subtitling: A new pedagogical resource for audiovisual translation students. Current Trends in Translation Teaching and Learning E, 8, 359 - 393. https://doi.org/10.51287 /cttle20218

Figure 2. Use of translator's extradiegetic notes. Source: Zdenek (2015).

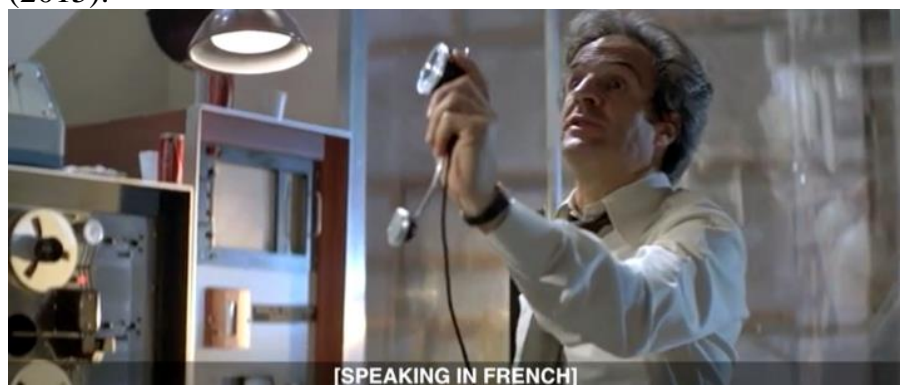

\section{ToT11. Rewording for acceptability purposes}

ToT11 involves rewording owing to tastes, social norms (e.g. censorship, political correctness, politeness, respectability) in the target culture or due to the style imposed by the client or producer. ToT11 may be related to, or account for, other ToTs (like 1, 3, or 5); e.g. reduced number, explicitness or strength of blasphemy or vulgar language. Examples of ToT11 are presented in (18) and (19). In (18), the slang word minge/coño is translated by the formal term (vagina).

(18) T1: Minge.

T2: La vagina.

BT: The vagina.

No technique: Coño.

[Source: 03]

In (19), a conventionalised euphemism in Spanish (acostarse con alguien, 'go to bed with somebody') is used to translate the expression to have sex[ual intercourse]. It is worth noting that 
Zabalbeascoa, P. and Arias-Badia, B. (2021). The HispaTAV translation techniques for subtitling: A new pedagogical resource for audiovisual translation students. Current Trends in Translation Teaching and Learning E, 8, 359 - 393. https://doi.org/10.51287 /cttle20218

the expression tener sexo con alguien, which we could interpret as a potential literal translation of T1 (No technique), has been traditionally perceived as a calque in Spanish, but is increasingly used in colloquial register. In this example, we also find an added question tag in the $\mathrm{T} 2$ that is not present in the $\mathrm{T} 1$, an element that contributes to portraying colloquial register and which may affect character portrayal (ToT1c, ToT12).

(19) T1: I'm not doing this because I want to have sex with you. T2: No lo hago porque quiera | acostarme contigo, ¿vale? BT: I don't do it because I want to lie in bed with you, ok? No technique: No hago esto porque quiera tener sexo / relaciones sexuales contigo.

[Source: 07]

\section{ToT12. Rewording for character portrayal purposes}

ToT12 typically overlaps with one or more of the previous techniques. It applies whenever the solution found is intended to show or emphasise a personality feature of the character speaking (example 16).

\section{ToT13. Combination of techniques}

ToT13 involves the combination of two or more of the other ToTs (as shown in examples 10, 12, 15, or 19). If this label is used in a descriptive study of translations, it is convenient to establish which of the combined techniques seems to play a major role in the solution under analysis. 
Zabalbeascoa, P. and Arias-Badia, B. (2021). The HispaTAV translation techniques for subtitling: A new pedagogical resource for audiovisual translation students. Current Trends in Translation Teaching and Learning E, 8, 359 - 393. https://doi.org/10.51287 /cttle20218

\section{PEDAGOGICAL EXPERIENCE AND NEXT STEPS}

The above proposal was presented to $3^{\text {rd }}$-year students of the BA in Translation and Interpreting as part of the subject Translation and the Media at the Universitat Pompeu Fabra (Barcelona, Spain). Upon presentation, we asked students to provide examples for each ToT. In doing so, we pursued a twofold aim: first, we wanted to assess the usefulness of the aprioristic list for the analysis of real translation samples, as well as gather insights on the extent to which the proposal was understandable for translation students (the main recipient of the created resource, to our mind); ultimately, we wanted to improve the students' own awareness and competence in translating.

The specific exercise proposed to students can be consulted in the Annex to this paper. In broad terms, they were asked to a) watch subtitled material available on streaming platforms with an analytical eye; b) describe the solutions they found, by using the HispaTAV framework, as well as any other previous accounts of translation techniques that they found useful for their analysis; and c) hypothesise about further possible solutions and compare them with the published material. Finally, the exercise requested a brief reflection on their understanding of the HispaTAV proposal and the difficulty entailed in finding specific types of translation techniques in mainstream subtitling practice. 
Zabalbeascoa, P. and Arias-Badia, B. (2021). The HispaTAV translation techniques for subtitling: A new pedagogical resource for audiovisual translation students. Current Trends in Translation Teaching and Learning E, 8, 359 - 393. https://doi.org/10.51287 /cttle20218

Overall, what we learnt from this teaching experience was that the students accepted, understood and appreciated the HispaTAV ToT proposal as much as and as easily as more traditional proposals, namely, Molina and Hurtado's. Their comments where they felt that Molina and Hurtado covered a specific technique (mostly modulation) that the ToTs did not cover were interpreted by us that in future we need to provide a fuller explanation of the possibilities and implications of the ToT proposal, given that we consider that modulation, for instance, is a type of rewording (ToT1). Of course, future students will benefit from all of the data and analysis provided by the students coming before them and the feedback given by the teachers, along with their corrections.

In this pedagogical experience, students did not provide any samples of ToT8b, 8c, or 10. This is understandable as ToT10 is much more characteristic of subtitling for the deaf and hard of hearing, where certain elements of the audio are explained, such as people speaking foreign languages. Likewise, ToT8b and 8c are more typical of fansubbing, or cybertranslation, and our students only searched for samples from professional subtitles. We deliberately mean to keep these techniques so that the forms can be filled in for data coming from such cases.

We trust that as the project grows and provides more and more data and analyses by means of the forms, the initial HispaTAV proposal can be refined and improved, and eventually become more stable, finer tuned for subtitling and better suited to being adapted beyond subtitling to other forms of AVT, including dubbing or cybertranslation. 
Zabalbeascoa, P. and Arias-Badia, B. (2021). The HispaTAV translation techniques for subtitling: A new pedagogical resource for audiovisual translation students. Current Trends in Translation Teaching and Learning E, 8, 359 - 393. https://doi.org/10.51287 /cttle20218

\section{ACKNOWLEDGEMENTS}

The first edition of the HispaTAV types of translation techniques proposal (Zabalbeascoa, 2021) was written with the collaboration of the following HispaTAV members, who are AVT scholars and professionals: Blanca Arias, Montse Corrius, Mariana Costa, Eva Espasa, Aida Franch, Anjana Martínez, Guillermo Parra, Rosa Roig, Damián Santilli, and Stavroula Sokoli.

This research has been conducted in the framework of the MUFiTAVi project (EL MULTILINGÜISMO DE LA FICCIÓN AUDIOVISUAL Y SUS TRADUCCIONES PARA ESPAÑA EN PLATAFORMAS DIGITALES), funded by Spanish Ministry of Science, Innovation, and Universities (ref. PGC2018-099823-B-I00).

The authors also want to thank the students of Universitat Pompeu Fabra who welcomed the idea to work on the HispaTAV ToT proposal and have provided us with invaluable examples to illustrate it.

\section{REFERENCES}

Sources for the examples 
Zabalbeascoa, P. and Arias-Badia, B. (2021). The HispaTAV translation techniques for subtitling: A new pedagogical resource for audiovisual translation students. Current Trends in Translation Teaching and Learning E, 8, 359 - 393. https://doi.org/10.51287 /cttle20218

01 = The Good Doctor, season 3, episodes 1 and 4 (David Shore, 2019). Subtitled by Marc Balart. US production. Streamed on Prime Video.

02 = Brooklyn Nine-Nine, season 5, episode 1 (Tristam Shapeero, 2017). Unknown subtitler. US production. Streamed on Netflix.

03 = Sex Education, season 1, episodes 1 and 3 (Pedro Tena, 2018). Subtitled by Estefanía Prol Lusquiños. UK production. Streamed on Netflix.

04 = How I Met your Mother, season 1, episode 2 (Pamela Fryman \& Rob Greenberg, 2005). Unknown subtitler. US production. Streamed on Netflix.

05 = Mamma Mia! (Phyllida Lloyd, 2008). Unknown subtitler. US production. Streamed on Movistar Plus.

06 = Lucifer, season 1, episode 1 (Len Wiserman, 2016). Unknown subtitler. US production. Streamed on Netflix.

07 = Jane the Virgin, season 1, episode 1 (Jennie Snyder, 2014). Unknown subtitler. US production. Streamed on Netflix.

$08=$ The End of the F***ing World, season 1, episode 6 (Lucy Tcherniak, 2017). Unknown subtitler. UK production. Streamed on Netflix.

\section{Secondary sources}

Delabastita, D. (1993). There's a Double Tongue: An Investigation into the Translation of Shakespeare's Wordplay, with Special Reference to Hamlet. Rodopi.

Delabastita, D. (1996). Introduction. In D. Delabastita (Ed.), Wordplay and Translation (pp. 127-139). St Jerome. 
Zabalbeascoa, P. and Arias-Badia, B. (2021). The HispaTAV translation techniques for subtitling: A new pedagogical resource for audiovisual translation students. Current Trends in Translation Teaching and Learning E, 8, 359 - 393. https://doi.org/10.51287 /cttle20218

Díaz-Cintas, J. and Remael, A. (2021). Subtitling: Concepts and Practices. Routledge.

IRT Mediathek. (2020). Demo Video: Creative subtitles - design and mechanics.

YouTube. https://www.youtube.com/watch?v=4pH9j6hweDY

Krzeszowski, T. P. (2016). The Translation Equivalence Delusion: Meaning and Translation. Peter Lang.

Marco, J. (2004). Les tècniques de traducció (dels referents culturals): retorn per a quedar-nos-hi. Quaderns. Revista de traducció 11, 129-149.

Macmillan. (n.d.). shrink. In Macmillan Dictionary. Retrieved 23 April, 2021, from https://www.macmillandictionary.com/us/dictionary/briti sh/shrink_2.

Molina, L. \& Hurtado, A. (2001). Translation techniques revisited: a dynamic and functionalist approach. Meta 47(4), 398-512.

Newmark, P. (1988). Approaches to Translation. Prentice Hall. Toury, G. (1995). Descriptive Translation Studies and Beyond. John Benjamins.

Vinay, J.-P. and Darbelnet, J. (1958). Stylistique comparée du français et de l'anglais: méthode de traduction. Didier.

Zabalbeascoa, P. (2000). From techniques to types of solutions. In A. Beeby, D. Ensinger \& M. Presas (Eds.), Investigating Translation (pp. 117-127). John Benjamins.

Zabalbeascoa, P. (2004). Translating non-segmental features of textual communication. In G. Hansen, K. Malmkjær \& D. Gile (Eds.), Claims, Changes and Challenges in Translation Studies (pp. 99-111). John Benjamins. 
Zabalbeascoa, P. and Arias-Badia, B. (2021). The HispaTAV translation techniques for subtitling: A new pedagogical resource for audiovisual translation students. Current Trends in Translation Teaching and Learning E, 8, 359 - 393. https://doi.org/10.51287 /cttle20218

Zabalbeascoa, P. (2008). The nature of the audiovisual text and its parameters. In J. Díaz-Cintas (Ed.), The Didactics of Audiovisual Translation (pp. 21-37). John Benjamins.

Zabalbeascoa, P. (2018). Solution types for representing dubbed film and TV multilingual humour. In I. Ranzato and S. Zanotti (Eds.), Linguistic and Cultural Representation in Audiovisual Translation (pp. 165-183). Routledge.

Zabalbeascoa, P. (2021). Técnicas de traducción para la subtitulación según las TdT- HispaTAV. https://repositori.upf.edu/bitstream/handle/10230/46288/z abalbeascoa_hispatav.pdf?sequence $=1 \&$ is Allowed $=y$.

Zdenek, S. (2015). Cultural literacy, sonic allusions, and series awareness.

Reading

Sounds. http://readingsounds.net/chapter7/. 
Zabalbeascoa, P. and Arias-Badia, B. (2021). The HispaTAV translation techniques for subtitling: A new pedagogical resource for audiovisual translation students. Current Trends in Translation Teaching and Learning E, 8, 359 - 393. https://doi.org/10.51287 /cttle20218

\section{ANNEX - Exercise proposed to students about the HispaTAV ToT proposal}

Students are presented with the full list of 13 ToTs, along with a written explanation of the list as a whole, along with its goals and motivation, then item per item. They are then asked to answer the following items (A - R), using the ToT labels and terms as much as possible to provide subtitles as examples of ToTs. The exercise they are asked to do is in line with what more expert informants would be asked to do in a project that involved building a data bank of subtitling samples, although for the case of translator training it is done in a pedagogical context, prioritising didactic activities, goals and feedback. The items of the list below are fields in a form that students fill in as requested in the wording of each item $\mathrm{A}-\mathrm{R}$, designed so that students only have to fill in the data as quickly and standardised as possible, for comparability of the information provided by each student, and for easy access to the samples. Finally, the design of items like $\mathrm{E}$ and $\mathrm{G}$, among others, can serve as filters for browsing and searching in case the database grows to a considerable size.

The flexibility of the form even allows for it to be filled without using the above ToT proposal (i.e., by using their own words or by previously published typologies), although the point of the exercise is to test its theoretical and pedagogical usefulness. Below is the list of items (A-R) requested in the form to provide context (data and metadata) for each sample provided and as a means to build up a data bank of samples. 
Zabalbeascoa, P. and Arias-Badia, B. (2021). The HispaTAV translation techniques for subtitling: A new pedagogical resource for audiovisual translation students. Current Trends in Translation Teaching and Learning E, 8, 359 - 393. https://doi.org/10.51287 /cttle20218

A. Transcription of the T1 audio or what can be read on screen (in the latter case use all caps).

B. Faithful copy of the T2 subtitle(s). As shown on screen (orthotypography, line breaks ...), that correspond to item A.

C. Start and end time of A. (e.g. 01:12:33,077 - 01:12:37,361).

D. Start and end time of B. (e.g. the same as for C).

E. About the subtitle (T2): translator, year, country, AV format (DVD, VHS...) or platform \& region (e.g. Netflix Argentina), access date.

F. Any necessary contextualization, brief explanation of the communicative situation or communication act (between characters or with the audience or both, e.g. what one character is telling another, and what the director is trying to convey to the audience through the characters' words).

G. About the work (T1): title, season, episode, director, year, country (e.g. The Big Bang Theory; S07E22, "The Proton Transmogrification"; Mark Cendrowski; United States; 2014).

H. Relevant changes, like the ones in ToT1 but briefly stating the most salient features of change, e.g. passive>>active, word order, repetitions.

I. Prioritized type(s) of conservation, i.e., what is kept (in T2, from T1), in terms of tone, effect, contents, types of equivalence (discursive, conversation type, semantic, syntactic), type or effect of: humour, taboo, intended audience reaction.

J. Space-time adjustment and audiovisual fit. Which captioning criteria were used? What is the influence of the specific traits of producing subtitles? One-liner or two-liner. Paralinguistic considerations (punctuation, colours ...). Description of 
Zabalbeascoa, P. and Arias-Badia, B. (2021). The HispaTAV translation techniques for subtitling: A new pedagogical resource for audiovisual translation students. Current Trends in Translation Teaching and Learning E, 8, 359 - 393. https://doi.org/10.51287 /cttle20218

what comes before and after (verbal and non-verbal) and is necessary to justify or complement the ToT (explain the solution). Use of any symbols (e.g. emojis). Legibility criteria, including speed.

K. The ToT reference numbers (according to ToT list) that best apply, and, when possible, the subtype (e.g. 1b). Is the result shorter, longer, or as long as the answer for M?

L. Name of the technique if not included in the ToT list and has another author; provide the reference (transposition, by Vinay and Darbelnet; permutation, by Delabastita). It is important to acknowledge the earliest proposal or mention of the technique, when there are several authors with the same (or similar enough) technique, Newmark, Hurtado and Molina, Gottlieb, etc.

M. The solution for $\mathrm{T} 2$ without any ToT, i.e., a literal translation, or ideal transference (vs K) or some otherwise plausibly acceptable solution (correct if it were not for subtitling or if the subtitle were not subjected to the spacetime constraints of the moment), or simply a gloss. The idea is for the techniques to justify their existence as opposed to literal, close, or ideal solutions that are not applicable in that case.

N. Transcription of the dubbed version, the T2 audio (if available). Especially instances illustrating specific dubbing criteria (synchrony, euphony, declaimability, singability ...) vs solutions adapted to specific subtitling criteria.

O. The ToT reference numbers (according to Table 1) that best apply to the dubbed version, $\mathrm{N}$, (as in K). If no ToTs are appropriate, provide an explanation, or a technique proposed in a different source. 
Zabalbeascoa, P. and Arias-Badia, B. (2021). The HispaTAV translation techniques for subtitling: A new pedagogical resource for audiovisual translation students. Current Trends in Translation Teaching and Learning E, 8, 359 - 393. https://doi.org/10.51287 /cttle20218

P. Faithful copy of the accessible subtitle. Especially if one two relevant cases: (i) when clearly different to subtitles not sensitive to accessibility (but valid by all other standards); and (ii) solutions that can be valid for accessible and general public subtitles.

Q. Any other versions (found or proposed). Which ToTs are exemplified? e.g. the same ToT as the answer for $\mathrm{K}$ (with a better or worse solution)? Alternative solutions may be from a different region of the same language (solutions for Spanish from America vs from Spain), or different formats (cinema, $\mathrm{TV}$, video, internet), or hypothetical alternatives, proposed by the student.

R. Version(s) deemed erroneous, found or hypothetical (which ToT?). The main goal of items $\mathrm{A}-\mathrm{Q}$ is to provide versions deemed acceptable. So, this item is to provide contrast. The answer to $\mathrm{R}$ could be the same as for $\mathrm{M}$ when the factors of $\mathrm{R}$ and $\mathrm{M}$ are reflected in the same sample.

Items $\mathrm{N}-\mathrm{R}$ are optional and only meant to highlight the potential effectiveness of a given ToT, or a certain solution reflecting that ToT. 